\title{
INFLUENCE OF MORAL VALUES AND NORMS ON THE ACCUMU- LATION OF SOCIAL CAPITAL - ACTIVITY OF IGNACY TOKARCZUK, A BISHOP OF THE DIOCESE OF PRZEMYŚL
}

\section{Introduction}

In recent years, social capital has become a particularly popular subject of studies. Scientists have noted a strong correlation between the level of social capital and the sustainable development of society, especially in local and regional communities. A high level of social capital is an indicator of democratized social life and a prerequisite for the development of civil society. ${ }^{1}$ Studies have revealed that the resources of social capital in Poland are increasing, although in comparison to Western European countries where democracy is well-established some indices of this capital are clearly lower. ${ }^{2}$ Researchers attribute these differences to political and historical circumstances, especially the heritage of the totalitarian communist system. ${ }^{3}$ After 1989 communism in Poland transformed into post-communism, and many social dysfunctions were transposed from the previous era to the new reality. ${ }^{4}$ The social consequence of the almost half-century-long impact of the totalitarian system on the society is the low level of trust that Poles have in public institutions and in people from outside their closest circle of family and friends, as well as limited involvement in social organizations. ${ }^{5}$

Regular studies carried out in various regions of Poland have indicated that Podkarpacie, located in the south-eastern part of the country, has a relatively high

1 M. Michalewska-Pawlak, Możliwości i bariery rozwoju kapitału społecznego na obszarach wiejskich $w$ Polsce, in: Kapitat spoleczny - interpretacje, impresje, operacjonalizacja, red. M. Klimowicz, W. Bokajło, Warszawa 2010, p. 185.

2 J. Herbst, Kraina nieufności: kapitat społeczny, rozwój gospodarczy i sprawność instytucji publicznych w polskiej literaturze akademickiej, in: Szafarze darów europejskich. Kapitat społeczny a realizacja polityki regionalnej w polskich województwach Warszawa 2008, pp. 20-21.

3 F. Fukuyama, Trust. The Social Virtues and The Creation of Prosperity, New York 1995, p. 69.

4 J. Staniszkis, Postkomunizm. Próba opisu, Gdańsk 2001, pp. 198-216, 249v250; R. Legutko, Polska, Polacy i suwerenność, Kraków 2014, pp. 41-42.

5 W. Bokajło, Amerykańskie korzenie kapitału społecznego, in: Kapitał społeczny - interpretacje, impresje, operacjonalizacja, red. M. Klimowicz, W. Bokajło, Warszawa 2010, p. 32; J. Czapski, Kapitat społeczny, in: Diagnoza społeczna 2007. Warunki i jakość życia Polaków. Raport, red. J. Czapiński, T. Panek, Warszawa 2007, pp. 258-259. 
level of social capital compared to other provinces. In 2009, the level of general trust in Podkarpacie was $26.5 \%$, which is more than twice as high as the national average (13.3\%). The social involvement of local residents and their participation in social organizations was also two-fold higher than the national average. ${ }^{6}$ Researchers draw attention to the culture and historical tradition of this region, shaped in the past by social and political circumstances. In Podkarpacie there is a tradition of civic involvement, reflected in the activity of local government and participation in social organizations. People living in this region, which used to be within the borders of Galicia, could take advantage of the political, cultural and religious freedoms resulting from the autonomy of the region, which strengthened local patriotism. ${ }^{7}$ A characteristic social phenomenon was the strong people's movement that activated local farmers. ${ }^{8}$ During the period of communist enslavement, local people made themselves known for their non-standard social activity, focused on the construction of sacral architecture, which was a religious and social phenomenon. ${ }^{9}$

Archbishop Ignacy Tokarczuk, who was an Ordinary of the Przemyśl Diocese between 1966 and 1993, had unquestionable merits in stimulating the religious and social activity of people living in Podkarpacie, and in the development of local social capital. Tokarczuk was a leader of the regional religious community and played an important role in building social ties and networks, as well as in shaping pro-democratic attitudes and behaviours. His pastoral service led to the formation of well-rooted, strong and active local communities in the Diocese of Przemyśl, attached to tradition and the local area, highly religious and strongly linked to the local Catholic Church. Bearing in mind the wide spectrum of activity of Tokarczuk in the Przemyśl Diocese, the author of this article focused his research on selected aspects of this activity aimed at building the moral foundations of community life. The paper presents an attempt at scientific analysis of existing resources to give an answer to the following research problem: In what dimensions of community life did the reception

6 H. Kotarski, Kapitał ludzki i kapitat społeczny a rozwój województwa podkarpackiego, Rzeszów 2013, p. 151; A. Sułek, Doświadczenie i kompetencje obywatelskie Polaków, in: Diagnoza społeczna 2009. Warunki jakości życia Polaków. Raport, eds. J. Czapiński, T. Panek, 2009, p. 269; S. Pastuszka, Zróżnicowanie kapitału społecznego województw świętokrzyskiego i opolskiego. Analiza porównawcza, Kielce 2018, p. 41.

7 J. Bartkowski, Tradycja i polityka. Wpływ tradycji kulturowych polskich regionów na współczesne zachowania społeczne i polityczne, Warszawa 2003, pp. 156-169; M. Michalewska-Pawlak, Możliwości i bariery..., op. cit., pp. 192-193; J. Działek, Kapitał społeczny jako czynnik rozwoju gospodarczego w skali regionalnej i lokalnej w Polsce, Kraków 2011, p. 62

8 A. Podraza, Walki klasowo-polityczne chłopów rzeszowskich $w$ latach 1931-1939, in: Ruch ludowy na Rzeszowszczyźnie. Materiały z sesji naukowej zorganizowanej przez WK ZSL Rzeszowie z okazji 70-lecia ruchu ludowego, Lublin 1967, p. 101.

9 H. Szareyko, Nielegalne budownictwo sakralne jako fenomen religijno-społeczny. Studium na przykładzie diecezji przemyskiej, 2nd edition, supplemented and corrected, Wrocław 2008, pp. 12-13, 60 . 
of moral values and norms by Tokarczuk have the strongest impact on the generation of social capital among the people living in the Diocese of Przemyśl?

\section{The role of social values and norms in the development of social capital}

Social capital plays an important role in social development. Increase in this capital has a positive effect by stimulating the development of the community. Various concepts of social capital have been presented in the scientific literature. Researchers distinguish two important components of social capital: structural (a network of connections) and normative (trust). ${ }^{10}$ French sociologist Pierre Bourdieu emphasizes that social capital strongly depends on a durable network of relationships between members of a group, who support each other using resources possessed by this group. Individuals gain socially appreciated resources through the networks of contacts, numerous acquaintances, and membership in organizations or associations. ${ }^{11}$ Participation in the group gives the individual access to capital generated by all members of this group connected by mutual recognition and acquaintance. ${ }^{12}$ The use of available resources of social capital generates a permanent duty to the other individuals expressed as gratitude or friendship. ${ }^{13}$ The synergy view on social capital emphasizes the involvement of many entities to achieve common benefits. ${ }^{14}$ Similarly, American sociologist James Coleman draws attention to the fact that social capital is formed in groups where individuals connected by strong ties jointly pursue their own interests and achieve goals collectively. In this way, personal intentions and aspirations of group members transform into their common good created through positive interactions between people..$^{15}$ From this point of view, social capital is a feature of the social structure that supports the actions of active individuals taken within this

10 J. Działek, Kapitat spoleczny..., op.cit., p. 36.

${ }^{11}$ W. Goszczyński, Uwarunkowania procesu wzmacniania kapitału spotecznego, in: Kapital spoleczny - interpretacje, impresje, operacjonalizacja, red. M. Klimowicz, W. Bokajło, Warszawa 2010, p. 205; M. Klimowicz, Kapitat społeczny. Zagadnienia metodologiczne, in: Kapitat spoteczny - interpretacje, impresje, operacjonalizacja, red. M. Klimowicz, W. Bokajło, Warszawa 2010, p. 47.

12 P. Bourdieu., The Forms of Capital, in: Handbook of Theory and Research for the Sociology of Education, red. J. Richardson, New York 1986, pp. 241-258; P. Bourdieu, L.J.D. Wacquant, An Invitation to Reflexive Sociology, Chicago 1992, p. 104.

13 A.S. Bartelski, Kapitat spoteczny a dobro publiczne, in: Kapitat spoteczny-interpretacje, impresje, operacjonalizacja, red. M. Klimowicz, W. Bokajło, Warszawa 2010, p. 101.

14 W. Goszczyński, Uwarunkowania procesu ..., op. cit., p. 209.

15 J.S. Coleman, Foundations of social theory, London 1990, pp. 300-313; K. Sierocińska, Kapitat spoteczny. Definiowanie, pomiar i typy, "Studia Ekonomiczne" 2011, no. 1, pp. 71-72. 
structure. Coleman considered values and norms as well as the cooperative power of group members to be highly significant in generating social capital. ${ }^{16}$

American political scientist Robert Putnam believes that social capital relies on interpersonal relationships that are manifested in associational activity, in which trust is a vital element. ${ }^{17}$ Networks of civic engagement are the foundation for norms of reciprocity and foster the development of social trust. ${ }^{18}$ Trust is the key ingredient of social capital, expressed in the principle of reciprocity, which postulates repaying for the favours received, or allows individuals to expect people to behave similarly in the future. ${ }^{19}$. Putnam believes that social capital, which is a public good based on trust, norms and social ties implying participation in public life, makes public life democratic. ${ }^{20}$ The special importance of trust, social values and norms in the resources of social capital was articulated in research by Francis Fukuyama, an American political scientist. According to his concept, social capital is the property that has its source in widespread social trust. A trustful individual assumes that other members of the community are honest and cooperative, and their behaviour is guided by shared norms..$^{21}$ Therefore, a set of values and ethical norms shared by members of the group, enabling them to cooperate effectively, plays a decisive role in generating social capital. Adherence to the system of values and norms by group members gives them confidence in each other, and makes their activity more efficient. Mutual trust of group members enables the group to function more efficiently and is the foundation for cooperation to gain the common good. Ethical behaviours strengthening social ties and increasing group cohesion have a significant impact on the formation of social relations that bring gains for the group. The morality of group members is expressed through virtues such as truthfulness, honesty, reliability, diligence, responsibility, keeping promises, fulfilling obligations and reciprocity.

${ }^{16}$ E. Nowak, Rola Kościoła i religii w procesie tworzenia kapitału spolecznego w Polsce - perspektywa teorii sekularyzacji, in: Kapitał społeczny - interpretacje, impresje, operacjonalizacja, red. M. Klimowicz, W. Bokajło, Warszawa 2010, p. 172; M. Klimowicz, Kapitat społeczny..., op. cit., pp. 45, 47-48, 51; A.S. Bartelski, Kapitat społeczny..., op. cit., p. 105.

17 A. S. Bartelski, Kapitał społeczny..., op. cit., p. 103. W. Bokajło, Amerykańskie korzenie..., op. cit., p. 30; W. Goszczyński, Uwarunkowania procesu..., op. cit., pp. 204-205.

18 R.D. Putnam, Democracies in Flux. The Evolution of Social Capital in Contemporary Society, Oxford 2002, p. 8. Cf. R.D. Putnam, Bowling alone. The Collapse and Revival of American Community, New York, 2000, p. 33.

19 R.D. Putnam, Making Democracy Work. Civic Traditions in Modern Italy, Princeton 1993, p. 244; J. Dzwończyk, Koncepcja kapitału negatywnego i próba jej użycia do analizy jednostka - społeczeństw - państwo w III RP, in: Kapitat społeczny-interpretacje, impresje, operacjonalizacja, eds. M. Klimowicz, W. Bokajło, Warszawa 2010, p. 224; W. Bokajło, Amerykańskie korzenie..., op. cit., p. 30

20 W. Bokajło, Amerykańskie korzenie..., op. cit., p. 30; R.D. Putnam, Making Democracy..., op. cit., p. 33.

${ }^{21}$ F. Fukuyama, Trust. The Social..., op. cit., p. 38. 
Most norms in the society stem from religious systems..$^{22}$ Fukuyama assumes that social capital is created and transmitted through religion, other cultural mechanisms and tradition. ${ }^{23}$

The above-presented classical concepts suggest that the strength of social capital is determined by the following factors: social values and norms, trust between individuals and public trust, networks of social relationships, cooperation in a group, responsibility for the group and activity focused on gaining the common good. ${ }^{24}$ Respected social values and norms influence the establishment of social ties and networks, as well as the formation of organizations and associations. Norms can be deeply rooted in values related to God and justice, but there are also secular norms regulating human behaviour. ${ }^{25}$ The whole interpersonal space is axionormative because interactions between people are regulated by various norms. ${ }^{26}$ Communities permeated with moral relationships function better than other communities that do not have such relationships. ${ }^{27}$ It is easier to create an atmosphere of mutual trust in groups of individuals who are guided by certain moral principles, because the attitudes and behaviours of group members become predictable. Researchers analysing social life believe that groups are not formed at random, but are based on the approved and shared values and norms, as well as the willingness to sacrifice one's personal good for the good of the group. People who respect similar values, such as honesty, diligence, reliability, truthfulness and credibility, are able to cooperate more efficiently to gain the common good. Values and norms respected by group members generate the mutual trust that is the foundation of effective cooperation. ${ }^{28}$ Researchers claim that religious communities and groups in which individuals are guided by a religious normative system are the natural environment promoting the accumulation of social capital. Sociologist Piotr Sztompka has emphasized the role of religion in the development of social capital. He argues that belief in God is a quasi-capital and is an important factor in strengthening trustfulness. Mutual trust combined with religiosity gives a sense of solidarity, support and roots in the religious community. The internal stability of a religious community is enhanced by increasing the density and strength of interactions between people. Shared religious beliefs build trust inside religious communities, thereby increasing the level of social capital. ${ }^{29}$

${ }^{22}$ F. Fukuyama, Social capital, in: Culture matters, red. L.E. Harrison, S.P. Huntington, New York, 2001, p. 169.

${ }^{23}$ F. Fukuyama, Trust. The Social..., op. cit., p. 39.

24 M. Klimowicz, Kapitat społeczny..., op. cit., pp. 45, 51; E. Nowak, Rola Kościoła..., op. cit., p. 172.

25 F. Fukuyama, Trust..., op. cit., p. 38.

26 P. Sztompka, Kapitał społeczny. Teoria przestrzeni międzyludzkiej, Kraków 2016, p. 104.

27 P. Sztompka, Social capital..., op. cit., pp. 150, 153-154.

28 F. Fukuyama, Trust..., op. cit., pp. 20, 50.

29 P. Sztompka, Zaufanie. Fundament spoleczeństwa, Kraków 2007, pp. 290-291. Cf. J. Herbst, P. Swianiewicz, Kapitał społeczny Dolnego Ślaska i Małopolski na tle ogól- 


\section{Moral values and norms as the foundation of social capital}

In 1966 when Tokarczuk, as an Ordinary became the bishop of the Przemyśl Diocese, in his service he focused on the implementation of the provisions of the Second Vatican Council with special emphasis on recommendations regarding the revival of the religious Catholic laity and clergy. God was the supreme value to which all his activity was subordinated, and he accepted the Ten Commandments, recapitulated in the commandment to love God and thy neighbour, as the guiding set of ethical norms. In his pastoral programme, Tokarczuk combined theological and sociological goals. On the one hand, he focused on the development of religious life in the Przemyśl Diocese, and on the other hand, he intended to build strong social ties in order to integrate the society of the Podkarpacie region, atomized by the policy of the communist regime. Guided by the principles of the Ten Commandments he made attempts to create strong social ties based on the commandment of love and mutual trust. The foundation of social ties, networks of relationships and mutual trust, on which social capital relies, were to be universal ethical values and norms that link an individual with God and society, promoting the empowerment of individuals and their interaction with other people in order to achieve the common good. ${ }^{30}$

In Tokarczuk's opinion, brotherly love uniting people was decisive for creating social ties. Love helped transform social relations, making them free from hostility, distrust, hatred, indifference to injustice and violation of human rights. Bishop Tokarczuk believed that love is the strongest binder keeping people together, as well as the most powerful force that stimulates activity for the common good, including altruistic attitudes and behaviours. For this reason it can transform relationships between people and create a new way of life based on brotherhood, trust and cooperation. ${ }^{31}$ The truth had an equally integrating character for Tokarczuk. It is the basis of mutual trust, because it is difficult to imagine effective cooperation when individuals are uncertain or have doubts as to the truthfulness and credibility of their partners. Lack of truth triggers distrust, weakens social ties, breaks up the community and inevitably leads to the regression of social capital. ${ }^{32}$ Building social life based on a solid foundation of moral values and norms became the principal goal of

nopolskiego zróżnicowania regionalnego, in: Szafarze darów europejskich. Kapitat spoteczny a realizacja polityki regionalnej w polskich województwach, red. P. Swianewicz, M. Lackowska, A. Mielczarek, Warszawa 2008, p. 56.

30 T. Szczurek, Konsekracja oraz ingres do Bazyliki Katedralnej w Przemyślu J. E. Ks. Biskupa Ignacego Tokarczuka, „Kronika Diecezji Przemyskiej” 1966, no. 2, p. 44; A. Garbacz, Działalność duszpastersko-społeczna arcybiskupa Ignacego Tokarczuka, Rzeszów 2006, pp. 145-147.

31 I. Tokarczuk, Cywilizacja miłości, „Nasza Rodzina” 1986, no. 5, p. 26; I. Tokarczuk, Mitość jest sprawą najważniejsza, ,Niedziela” 28 (1985), no. 51-52, p. 7.

32 I. Tokarczuk, Myśl o kryzysie kultury, „Wiadomości Polskiej Myśli Katolickiej. Czyn Katolicki" 41 (1990), no. 2, p. 10. 
the religious and social activity of Bishop Ignacy Tokarczuk. He claimed that social order can be achieved through the observance of the principles provided in the Ten Commandments. Life without personal and social morality "simply becomes impossible." ${ }^{33}$ Bishop Tokarczuk believed that social order could not be established without adherence to universal moral principles. They are necessary to regulate social relations. Civilizations and societies that grossly violate the moral order and do not observe moral law become internally disintegrated and collapse. His standpoint was consistent with the belief of a prominent contemporary British philosopher, John N. Gray, who believes that moral norms are a prerequisite for the survival of society, because without them violence and social anomalies will triumph, and then the fate of a free society is doomed. ${ }^{34}$ For Tokarczuk, the observance of the moral standards established in the Ten Commandments was the basis and condition for the survival of society and its proper functioning. The role of the rules and norms of social life valued and respected by Bishop Tokarczuk was confirmed in sociological analyses concerning the development of social capital. People who accept the Ten Commandments are more likely to increase the resources of social capital than people who do not respect these universal moral principles. ${ }^{35}$ Thus, there is a strong correlation between the moral standards often accepted by citizens and the manifestations of social capital. ${ }^{36}$ In societies that respect moral law the manifestations of religious social capital are closely related to church morality, which has its source in religious moral norms ${ }^{37}$ When it comes to respecting the axiological system and creating a social order based on durable and stable moral principles, Tokarczuk did not see any chance for exceptions or compromise. He believed that individuals or groups which do not respect moral norms pose a serious threat to social order because they undermine their own freedom and that of other people, lose social trust, cause conflicts, tensions and divisions in society, and cause the disintegration of social ties. Thus, they destroy the natural foundations for the development of social capital and disable the sustainable development of civil society. One example of a threat to society given by Tokarczuk was communism, which by falsifying the truth about man and the transcendental aspect of his existence led to the dehumanization and disintegration of the system of moral principles. In the structure of a communist state that used lies, there could be no question of citizens trusting the authorities and public institutions. ${ }^{38} \mathrm{In}$ a totalitarian state, society was divided into dominant and subordinate groups. The

33 I. Tokarczuk, Kazania pasterskie 1966-1992, Przemyśl 1992, p. 270.

34 P. Sztompka, Kapitat spoteczny..., op. cit., p. 150.

35 W. Sadłoń, Religijny kapitał społeczny. Kapitat społeczny a Kościót katolicki w społecznościach lokalnych w Polsce, Saarbrücken 2014, p. 175.

36 W. Sadłoń, Religijny kapitał..., op. cit., p. 176.

37 Cf. J. Mariański, Moralność religijna jako przedmiot badań socjologicznych, in: Socjologia życia religijnego w Polsce, red. S. Zaręba, Warszawa 2009, pp. 253-276.

38 You cannot betray the gospel. Conversations with Archbishop Ignacy Tokarczuk, red. M. Krzysztofiński, Rzeszów-Kraków 2012, pp. 51-52. 
interests of classes and groups clashed, dividing the society and generating conflicts that manifested in the class struggle disintegrating the society. Respect for the role of moral norms in public life kept Tokarczuk away from seeking a compromise with the communists. Tokarczuk was a staunch opponent of the totalitarian regime, publicly criticized its anti-humanist ideology and activities, and strongly criticised the violation of human rights by communists. At the same time, he supported the establishment and development of the democratic opposition. Thanks to his involvement in the defence of human dignity and rights and in the creation of independent anti-communist structures, Przemyśl was a foothold of freedom in times of enslavement, and Podkarpacie became the hub of the rural 'Solidarity' movement. ${ }^{39}$ The anti-communist activity of Tokarczuk was received with hostility by the communist authorities, which carried out well-organized operations against him. ${ }^{40}$

Tokarczuk's most spectacular achievement in the field of activating Catholics was the movement focused on the construction of sacral architecture that he stimulated. Well integrated and active parish communities, for which it was normal to cooperate based on trust, built - in spite of repressions from the communist authorities - about 400 churches without relevant permits, and also about 400 other sacral objects of architecture, which was an unprecedented religious and social phenomenon. ${ }^{41}$ This process had a positive effect on the religiosity of Catholics, increased their commitment, empowered them, and strengthened the bond between local people and the parish. ${ }^{42}$

39 J. Draus, Arcybiskup Ignacy Tokarczuk a opór społeczny w diecezji przemyskiej, "Studia Rzeszowskie" 2003, no. 10, p. 111; J. Szkutnik, Komitet Samoobrony Chłopskiej Ziemi Rzeszowskiej, "Studia Rzeszowskie" 1995, vol. 2, pp. 137-138; J. Klus, Trwamy. Serwis Informacyjny. Wydanie okolicznościowe , Serwisu Informacyjnego” Zarzadu Regionu NSZZ , Solidarność” w Rzeszowie poświęcone XV rocznicy podpisania Porozumień Rzeszowsko-Ustrzyckich 19.02.1981 - 19.02.1996, 1996, p. 2.

40 J. Żaryn, Biskupi polscy doby PRL jako przedstawiciele polskich elit, in: Biskupi w rzeczywistości politycznej Polski ,,ludowej”, red. R. Łatka, Warszawa 2020, pp. 28-31; J. Żaryn, Rola biskupa Ignacego Tokarczuka w pracach Rady Głównej Konferencji Episkopatu Polski, in: Niezłomny. Pamięci księdza arcybiskupa Ignacego Tokarczuka w setna rocznice urodzin, Warszawa 2019, pp. 18-25.

${ }^{41}$ M. Rudnicka, Budownictwo sakralne misja trudnych czasów, in: Księga jubileuszowa 25 lat pasterskiego postugiwania ks. biskupa Ignacego Tokarczuka, red. J.F. Adamski, M. Rudnicka, Brzozów-Stalowa Wola 1991, p. 91. Cf. Annual journal: Schematyzm diecezji przemyskiej 1990, Przemyśl 1991, p. 498.

${ }^{42}$ K. Bełch, Strategie duszpasterskie arcybiskupa Ignacego Tokarczuka, in: Arcybiskup Ignacy Tokarczuk w oczach spoleczeństwa, red. J. Zimny, Sandomierz 2003, pp. 226-227; K. Bełch, Dynamika przemian zachowań religijno-moralnych katolików $w$ warunkach tworzenia nowych parafii. Studium socjologiczne na przykładzie diecezji przemyskiej w latach 1966-1985, Przemyśl 1990, pp. 201-203; W. Jedynak, Wpływ budownictwa sakralnego na zmiany zachowań religijno-moralnych katolików $w$ diecezji przemyskiej, 
The realistic assessment of communism by Tokarczuk meant that not only did he disapprove of dealing with communists, but he was a staunch opponent of negotiating with them during The Polish Round Table Talks in 1989. ${ }^{43}$ His standpoint was unique among the members of the Polish episcopate, when the vast majority of bishops supported the idea of the Round Table Talks. Tokarczuk believed that the communists could not be trusted, and any compromise concluded with them would violate moral values and norms because it eliminated the difference between good and evil, and would ensure impunity for the people of the regime who operated criminal activity during the times of the People's Republic of Poland. ${ }^{44}$ Another threat to the axiological system noted by Tokarczuk after the fall of communism was liberal democracy promoting moral relativism. This relativism was manifested in practical materialism, a variant of Marxist mainstream ideology recognizing the primacy of material goods over spirituality. Practical materialism, despite being a mutant Marxism, indicates other priorities in human life than communism. It promotes prosperity, consumption, unlimited freedom and moral relativism that does not recognize durable and stable norms. Material goods become an end, not a means to an end..$^{45}$ Moreover, practical materialism empowers individualism, weakening social solidarity, and causes the breakdown of social ties. ${ }^{46}$ Bishop Tokarczuk believed that freedom, in liberalism considered the supreme value, must have established limits. The unlimited freedom of some people is a threat to the freedom of other individuals or groups. Those who exploit their freedom pose a real threat to the proper functioning of society. Absolutizing freedom leads to axiological chaos and causes a degeneration of social life. A society that does not want to respect any moral limitations and rejects ethical principles is a society focused on the unlimited exploitation of freedom, which poses a threat to the existence of modern civilization. ${ }^{47}$ Therefore, human freedom must be protected by a system of moral norms that define its limits. ${ }^{48}$

Bishop Ignacy Tokarczuk was concerned about neo-Marxism, because by questioning Christian values that for centuries shaped cultural identity in Europe, it became the leading ideology in the European Union. Restricting societies of the EU to a single vision of human development based on ideology referring to the left-liberal

„Społeczeństwa i Rodzina” 2010, no. 23, p. 17; H. Szareyko, Nielegalne budownictwo..., op. cit., p. 432.

${ }^{43}$ M. Krzysztofiński, Arcybiskup Ignacy Tokarczuk 1918-2020 metropolita przemyski obrzadku łacińskiego, Rzeszów-Warszawa 2019, p. 65.

44 R. Łatka, Episkopat polski wobec stosunków państwo-Kościół i rzeczywistości społecznopolitycznej PRL 1970-1989, Warszawa 2019, p. 767.

45 I. Tokarczuk, Problemy spoleczne w świetle Ewangelii, „Niedziela” 32 (1989), no. 31, p. 4.

46 I. Tokarczuk, Moc i wytrwałość, red. T. Fiałkowski, J. Illg, 2nd edition, Kraków 1997, p. 50.

${ }^{47}$ I. Tokarczuk, Moc $i$ wytrwatość, op. cit., p. 153. Cf. H. Dudzińska, Pierwsi arcybiskupi przemyscy, „Przegląd Kolbuszowski” (1993), no. 19, p. 11.

48 I. Tokarczuk, Moc $i$ wytrwałość, op. cit., p. 153. 
doctrine made it difficult to generate social capital and to develop civil society. ${ }^{49}$ Tokarczuk predicted that if social life in the European Union is not built on universal moral values and norms, i.e. on the axiological roots of Western civilization, its structures would disintegrate, and the European Union would share the fate of other empires that internally disintegrated because of moral relativism.

Tokarczuk was convinced that the attempts to eradicate religious morality from social life made by communists and liberal democrats can be a threat to the development of social capital and building a pluralistic civil society. His concerns were confirmed by the research of Robert Putnam, who was convinced that the religious commitment and religious morality of citizens are directly related to social activity, and thus to social capital. Those believing in God are more likely to trust other people and to engage in social relationships than atheists or agnostics. Meanwhile, secularization generating the indifference of citizens to religious and social affairs, and triggering permissiveness and moral relativism, significantly limits and impoverishes the network of social relationships, and has a negative effect on social capital. ${ }^{50}$ No doubt, the pastoral activity of Tokarczuk was aimed at opposing the secularization of Polish society, the goal which communist authorities tried to achieve through administrative measures, and then new left-liberal elites after the fall of communism. Bishop Tokarczuk knew that the weak religiosity and morality of the Poles would have a negative impact on the development of social ties and the level of social trust, and thus would lower social capital. Therefore, in matters of morality, he did not accept compromises in relations either with secular or ecclesiastical authorities. Attention should also be drawn to the opinions of members of the episcopate on the role of values and norms in the attitudes and behaviour of Abp. Tokarczuk. Archbishop Tadeusz Gocłowski reported that Tokarczuk was both right and demanding, and "had very few friends because of his intransigence." 51 During the 31 years of his bishopric service, Gocłowski did not meet "another person with such a positive and unique profile of traits." ${ }^{52}$ According to Bishop Edward Frankowski, Tokarczuk "knew how to cut himself off from people who, for some reason, succumbed to weakness, and gave up rules and principledness in matters of the Church or the good of the nation." ${ }^{53}$ Archbishop Alfons Nosol also insists that "Tokarczuk was able to oppose anyone in the defence of truth and morality. Regardless of his likes or dislikes, or the position of his interlocutor, he openly defended moral values

49 I. Tokarczuk, Nie bądźmy bierni, „Nowiny” (1993), no. 75, p. 4. Unauthorized transcript of the homily delivered on 11 April 1993 by Archbishop I. Tokarczuk at the Metropolitan Basilica in Przemyśl,

${ }^{50}$ E. Nowak, Rola Kościoła..., op. cit., p. 176.

${ }^{51}$ Account of Abp. Tadeusz Goctowski, in: Non omnis morial. Arcybiskup Ignacy Tokarczuk we wspomnieniach, red. M. Krzysztofiński, Rzeszów 2016, p. 156.

${ }_{52}$ Account of Abp. Tadeusz..., op. cit., p. 157

53 Wywiad z bpem Edwardem Frankowskim, in: I. Tokarczuk, Z przemyskiej ,,twierdzy”, red. L. Żbikowska, part 1, Marki-Struga 1999, p. 47. 
and norms. ${ }^{" 54}$ A similar opinion was expressed by Marian Przykucki, the bishop of Szczecin and Kamień, who said that Tokarczuk "was able to oppose anyone, be it a minister or a party secretary, in the name of truth and in defence of human rights." $" 55$ Tokarczuk's transparent stance on moral issues also earned the recognition and respect of the leaders of the anti-communist opposition. Andrzej Czuma, an activist in independence organizations, recalls that the bishop of Przemyśl focused on durable values and built relationships with people on them: He placed God's law higher than the law made by people. According to Czuma, Tokarczuk was one of the few hierarchs who, in social relations, did not merchandise God's law in order to achieve some mundane goals. ${ }^{56}$

\section{Concluding remarks}

Moral values and norms play a decisive role in the accumulation of social capital. Thanks to them, mutual trust is built between individuals, determining the formation of social ties and networks. Values and norms shared by individuals inspire associational activity, since citizens who trust each other more easily interact and associate in non-governmental organizations. Socially approved norms organize social life and enable its sustainable development.

Appreciating the importance of moral values and norms in social life, Tokarczuk decided to use them as the foundation of human activity. He assumed that the adoption of a system in which God is the supreme value, as well as preserving the moral law established by God, would put in order the functioning of the community in the religious and secular aspects. The conducted analysis revealed that the moral values and norms promoted by Tokarczuk in social life increased the resources of social capital among the people living in the Diocese of Przemyśl. A particularly important manifestation of the development of social capital was the increase in the social activity of lay Catholics, reflected in the cooperation of local communities that formed the movement for the construction of sacral architecture, organizing new parishes and creating parish groups and associations. There was also an increase in the level of religiosity, altruistic attitudes and social behaviours focused on the common good of local communities. Trust in other participants of social life, based on respected moral values and norms, strengthened social ties and networks and facilitated cooperation within organized groups. People who approved and upheld moral standards were perceived by others as predictable, reliable and trustworthy. These virtues were particularly important during the communist period, when people had to consider the

${ }^{54}$ Account of Abp. Alfons Nosol, in: Non omnis morial. Arcybiskup Ignacy Tokarczuk we wspomnieniach, red. M. Krzysztofiński, Rzeszów 2016, p. 262.

55 M. Przykucki, W hołdzie arcybiskupowi Ignacemu Tokarczukowi, in: Arcybiskup Tokarczuk w oczach społeczeństwa, red. J. Zimny, Sandomierz 2003, p. 191.

56 Account of Andrzej Czuma, in: Non omnis morial. Arcybiskup Ignacy Tokarczuk we wspomnieniach, red. M. Krzysztofiński, Rzeszów 2016, p. 84. 
risk of being invigilated and denounced. Tokarczuk's emphasis on moral behaviour in social activity promoted stronger patriotism and the dynamic development of opposition and independence structures in the Przemyśl Diocese. It also increased the attachment of people to traditional values, shaping certain attitudes and behaviours. The majority of the residents of the Podkarpacie region have consistently supported parties and candidates declaring their attachment to religious and patriotic values in political elections since 1989. The social phenomena presented above lead to the conclusion that the reception of moral values and norms in social life, carried out for many years in the Przemyśl Diocese by Tokarczuk, clearly dynamized the development of social capital, both in religious and secular communities.

\section{References}

\section{Printed sources}

Account of Abp. Alfons Nosol, in: Non omnis morial. Arcybiskup Ignacy Tokarczuk we wspomnieniach, red. M. Krzysztofiński, Rzeszów 2016, pp. 261-264.

Account of Abp. Tadeusz Goctowski, in: Non omnis morial. Arcybiskup Ignacy Tokarczuk we wspomnieniach, red. M. Krzysztofiński, Rzeszów 2016, pp. 155-157.

Account of Andrzej Czuma, in: Non omnis morial. Arcybiskup Ignacy Tokarczuk we wspomnieniach, red. M. Krzysztofiński, Rzeszów 2016, pp. 83-87.

Schematyzm diecezji przemyskiej 1990, Przemyśl 1991.

Tokarczuk I., Kazania pasterskie 1966-1992, Przemyśl 1992.

Tokarczuk I., Miłość jest sprawa najważniejsza, „Niedziela” 28 1985, no. 51-52, pp. $1,7$.

Tokarczuk I., Myśl o kryzysie kultury, „Wiadomości Polskiej Myśli Katolickiej. Czyn Katolicki” 41 (1990), no. 2, pp. 9-12.

Tokarczuk I., Nie bądźmy bierni, „Nowiny” 1993, no. 75, p. 4.

Tokarczuk I., Problemy społeczne w świetle Ewangelii, „Niedziela” 32 (1989), no. 31, pp. 1, 4-5.

Wywiad z bpem Edwardem Frankowskim, in: I. Tokarczuk, Z przemyskiej „twier$d z y$ ”, red. L. Żbikowska, part 1, Marki-Struga 1999, pp. 36-48.

\section{Elaborations}

Bartelski A.S., Kapitat spoleczny a dobro publiczne, in: Kapitat spoleczny - interpretacje, impresje, operacjonalizacja, red. M. Klimowicz, W. Bokajło, Warszawa 2010, pp. 97-112.

Bartkowski J., Tradycja i polityka. Wpływ tradycji kulturowych polskich regionów na wspótczesne zachowania spoteczne i polityczne, Warszawa 2003. 
Bełch K., Dynamika przemian zachowań religijno-moralnych katolików w warunkach tworzenia nowych parafii. Studium socjologiczne na przykładzie diecezji przemyskiej w latach 1966-1985, Przemyśl 1990.

Bełch K., Strategie duszpasterskie arcybiskupa Ignacego Tokarczuka, in: Arcybiskup Ignacy Tokarczuk w oczach spoleczeństwa, red. J. Zimny, Sandomierz 2003, pp. 217-228.

Bokajło W., Amerykańskie korzenie kapitatu społecznego, in: Kapitat społeczny interpretacje, impresje, operacjonalizacja, red. M. Klimowicz, W. Bokajło, Warszawa 2010, pp. 19-42.

Bourdieu P., The Forms of Capital, in: Handbook of Theory and Research for the Sociology of Education, red. J. Richardson, New York 1986.

Bourdieu P., Wacquant L.J.D., An Invitation to Reflexive Sociology, Chicago 1992.

Coleman J.S., Foundations of social theory, London 1990.

Czapski J., Kapitat społeczny, in: Diagnoza Społeczna 2007. Warunki i jakość życia Polaków, red. J. Czapiński, T. Panek, Warszawa 2007, pp. 257-267.

Draus J., Arcybiskup Ignacy Tokarczuk a opór społeczny $w$ diecezji przemyskiej, „Studia Rzeszowskie” 2003, no. 10, pp. 109-116.

Dudzińska H., Pierwsi arcybiskupi przemyscy, „Przegląd Kolbuszowski” 1993, no. 19, pp. 10-11.

Działek J., Kapitat społeczny jako czynnik rozwoju gospodarczego w skali regionalnej i lokalnej w Polsce, Kraków 2011.

Dzwończyk J., Koncepcja kapitału negatywnego i próba jej użycia do analizy jednostka - spoteczeństw - państwo w III RP, in: Kapitat spoteczny - interpretacje, impresje, operacjonalizacja, red. M. Klimowicz, W. Bokajło, Warszawa 2010, pp. 223-236.

Garbacz A., Działalność duszpastersko-społeczna arcybiskupa Ignacego Tokarczuka, Rzeszów 2006.

Goszczyński W., Uwarunkowania procesu wzmacniania kapitału społecznego, in: Kapitał społeczny - interpretacje, impresje, operacjonalizacja, red. M. Klimowicz, W. Bokajło, Warszawa 2010, pp. 203-222.

Fukuyama F., Social capital, in: Culture matters, red. L.E. Harrison, S.P. Huntington, New York, 2001.

Fukuyama F., Trust. The Social Virtues and The Creation of Prosperity, New York 1995.

Herbst J., Kraina nieufności: kapitat społeczny, rozwój gospodarczy i sprawność instytucji publicznych w polskiej literaturze akademickiej, in: Szafarze darów europejskich. Kapitat spoteczny a realizacja polityki regionalnej w polskich województwach, Warszawa 2008, pp. 20-53.

Herbst J., Swianiewicz P., Kapitat społeczny Dolnego Ślaska i Małopolski na tle ogólnopolskiego zróżnicowania regionalnego, in: Szafarze darów europejskich. 
Kapitat społeczny a realizacja polityki regionalnej $w$ polskich województwach, Warszawa 2008, pp. 54-124.

Jedynak W., Wplyw budownictwa sakralnego na zmiany zachowań religijno-moralnych katolików w diecezji przemyskiej, „Społeczeństwa i Rodzina” 2010, no. 23, pp. 8-22.

Klimowicz M., Kapitat społeczny. Zagadnienia metodologiczne, in: Kapitat spolecz$n y$ - interpretacje, impresje, operacjonalizacja, red. M. Klimowicz, W. Bokajło, Warszawa 2010, pp. 43-52.

Klus J., Trwamy. Serwis Informacyjny. Wydanie okolicznościowe „Serwisu Informacyjnego” Zarzadu Regionu NSZZ „Solidarnośc”” w Rzeszowie poświęcone XV rocznicy podpisania Porozumień Rzeszowsko-Ustrzyckich 19.02.1981 19.02.1996, p. 2.

Kotarski H., Kapitat ludzki i kapitat społeczny a rozwój województwa podkarpackiego, Rzeszów 2013.

Krzysztofiński M., Arcybiskup Ignacy Tokarczuk 1918-2020 metropolita przemyski obrządku łacińskiego, Rzeszów-Warszawa 2019.

Legutko R., Polska, Polacy i suwerenność, Kraków 2014.

Łatka R., Episkopat polski wobec stosunków państwo-Kościót i rzeczywistości spotecznopolitycznej PRL 1970-1989, Warszawa 2019.

Mariański J., Moralność religijna jako przedmiot badań socjologicznych, in: Socjologia życia religijnego w Polsce, red. S. Zaręba, Warszawa 2009, pp. 253-276.

Michalewska-Pawlak M., Możliwości i bariery rozwoju kapitału spotecznego na obszarach wiejskich $w$ Polsce, in: Kapitat spoteczny - interpretacje, impresje, operacjonalizacja, red. M. Klimowicz, W. Bokajło, Warszawa 2010, p. 185-202.

Nowak E., Rola Kościoła i religii w procesie tworzenia kapitału społecznego w Polsce - perspektywa teorii sekularyzacji, in: Kapitat społeczny - interpretacje, impresje, operacjonalizacja, red. M. Klimowicz, W. Bokajło, Warszawa 2010, pp. 173-184.

Pastuszka S., Zróżnicowanie kapitału społecznego województw świętokrzyskiego i opolskiego. Analiza porównawcza, Kielce 2018.

Podraza A., Walki klasowo-polityczne chłopów rzeszowskich w latach 1931-1939, in: Ruch ludowy na Rzeszowszczyźnie. Materiały z sesji naukowej zorganizowanej przez WK ZSL w Rzeszowie z okazji 70-lecia ruchu ludowego, red. S. Jarecka-Kimlowska, Lublin 1967, pp. 101-191.

Putnam R.D., Democracies in Flux. The Evolution of Social Capital in Contemporary Society, Oxford 2002.

Putnam R.D., Making Democracy Work. Civic Traditions in Modern Italy, Princeton 1993.

Putnam R.D., Bowling alone. The Collapse and Revival of American Community, New York 2000. 
Przykucki M., W hołdzie arcybiskupowi Ignacemu Tokarczukowi, in: Arcybiskup Ignacy Tokarczuk $w$ oczach społeczeństwa, red. J. Zimny, Sandomierz 2003, pp. 190-191.

Rudnicka M., Budownictwo sakralne misja trudnych czasów, in: Księga jubileuszowa 25 lat pasterskiego postugiwania ks. biskupa Ignacego Tokarczuka, red. J.F. Adamski, M. Rudnicka, Brzozów-Stalowa Wola 1991, pp. 85-97.

Sadłoń W., Religijny kapitał społeczny. Kapitat społeczny a Kościół katolicki w spotecznościach lokalnych w Polsce, Saarbrücken 2014.

Sierocińska K., Kapitat społeczny. Definiowanie, pomiar i typy, „Studia Ekonomiczne" 2011, no. 1, pp. 69-86.

Staniszkis J., Postkomunizm. Próba opisu, Gdańsk 2001.

Szareyko H., Nielegalne budownictwo sakralne jako fenomen religijno-spoleczny. Studium na przykladzie diecezji przemyskiej, 2nd edition, supplemented and corrected, Wrocław 2008.

Szczurek T., Konsekracja oraz ingres do Bazyliki Katedralnej w Przemyślu J. E. Ks. Biskupa Ignacego Tokarczuka, „Kronika Diecezji Przemyskiej” 1966, no. 2, pp. 40-48.

Szkutnik J., Komitet Samoobrony Chłopskiej Ziemi Rzeszowskiej, „Studia Rzeszowskie" 1995, vol. 2, pp. 135-143.

Sułek A., Doświadczenie i kompetencje obywatelskie Polaków, in: Diagnoza Spoteczna 2009. Warunki i jakość życia Polaków, red. J. Czapiński, T. Panek, Warszawa 2009, pp. 265-270.

Sztompka P., Kapitat społeczny. Teoria przestrzeni międzyludzkiej, Kraków 2016.

Sztompka P., Zaufanie. Fundament spoteczeństwa, Kraków 2007.

Tokarczuk I., Cywilizacja miłości, „Nasza Rodzina” 1986, no. 5, pp. 24-31.

Tokarczuk I., Moc i wytrwałość, red. T. Fiałkowski, J. Illg, 2nd edition, Kraków 1997.

Żaryn J., Biskupi polscy doby PRL jako przedstawiciele polskich elit, in: Biskupi w rzeczywistości politycznej Polski ,,ludowej”, Warszawa 2020, pp. 15-34.

Żaryn J., Rola biskupa Ignacego Tokarczuka w pracach Rady Głównej Konferencji Episkopatu Polski, in: Niezłomny. Pamięci księdza arcybiskupa Ignacego Tokarczuka w setna rocznicę urodzin, Warszawa 2019, pp. 17-26.

\section{Wpływ wartości i norm moralnych na akumulację kapitału społecznego na przykładzie aktywności biskupa przemyskiego Ignacego Tokarczuka}

\section{Streszczenie}

Celem badań analitycznych zrealizowanych w oparciu o źródła zastane było ustalenie korelacji między aktywnością abp Ignacego Tokarczuka polegającą na recepcji 
wartości i norm moralnych w życiu społecznym a rozwojem kapitału społecznego w diecezji przemyskiej. Przedsięwzięcia inicjowane przez duchownego, w których szczególną uwagę zwracał na zachowywanie prawa moralnego pozytywnie wpływały na więzi społeczne, gęstość sieci powiązań oraz na wzrost zaufania społecznego. Przekonanie o przewidywalnym zachowaniu partnerów w trakcie współdziałania, a także kierowanie się uznawanymi wspólnie wartościami i normami moralnymi sprzyjało rozwojowi aktywności stowarzyszeniowej, a także dynamizowało prace zespołowe. Siły poszczególnych jednostek połączone dzięki kooperacji pozwalały z większą skutecznością realizować zadania mające na celu dobro wspólne społeczności lokalnych. Efekty współdziałania były pożyteczne zarówno dla wspólnot religijnych, jak i społeczności świeckich. Dynamicznie rozwijał się ruch budownictwa sakralnego, zwiększała się aktywność stowarzyszeniowa oraz wzrastał poziom religijności. Ożywieniu ulegała również aktywność antykomunistycznych organizacji niepodległościowych, domagających się demokratyzacji życia społecznego. Wskazywane i wdrażane przez Tokarczuka uniwersalne wartości oraz normy moralne dawały postawy aksjologiczne pod budowę społeczeństwa obywatelskiego.

Słowa klucze: wartości, normy moralne, kapitał społeczny, więzi społeczne, współdziałanie, zaufanie

\section{Summary}

The aim of this analytical study carried out based on the existing sources was to determine the correlation between the activity of Archbishop Ignacy Tokarczuk involving the reception of moral values and norms in social life and development of social capital in the Diocese of Przemyśl. Projects initiated by Abp. Tokarczuk, in which he put special emphasis on the observance of moral law, had a positive effect on social ties, the number of connections, and the increase of social trust. Belief in the predictable behaviour of cooperating partners, as well as adherence to moral values and norms shared by many individuals promoted the development of associational activity and made teamwork more dynamic. The powers of individuals joined in cooperation allowed for the more efficient execution of tasks aimed at the common good of local communities. Cooperation brought benefits to both religious and secular communities. The movement aimed at the construction of sacral architecture developed dynamically, and associational activity increased, as did the level of religiosity. The activity of anti-communist independence organizations, demanding the democratization of social life, was also stimulated. Universal moral values and norms emphasized and promoted by Tokarczuk created axiological foundations for the establishment of a civil society.

Key words: values, moral norms, social capital, social ties, cooperation, trust 